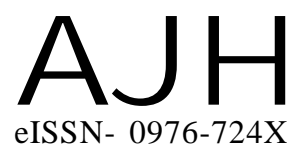

Article history :

Received : 07.05.2014

Revised : 04.10.2014

Accepted : 19.10.2014
Members of the Research Forum

Associated Authors:

${ }^{1}$ Department of Horticulture, Udai

Pratap Autonomous College,

VARANASI (U.P.) INDIA

${ }^{2}$ Department of Horticulture, N.D. University of Agriculture and Technology, Kumarganj, FAIZABAD (U.P.) INDIA
Author for correspondence J.K. SINGH

Department of Horticulture, N.D.

University of Agriculture and

Technology, Kumarganj, FAIZABAD

(U.P.) INDIA

Email : jitendra_hort@yahoo.com
THE ASIAN JOURNAL OF HORTICULTURE

Volume 9 | Issue 2 |Dec., 2014 |342-346

Visit us -www.researchjournal.co.in

\section{Integrated nutrient management studies on yield, physico-chemical characteristics and economic feasibility of bael (Aegle marmelos Correa) cv. NARENDRA BAEL-9}

\section{J. K. SINGH, D.K. SINGH ${ }^{1}$ AND H.K. SINGH ${ }^{2}$}

ABSTRACT : The present experiment was carried out, under sodic soil conditions at Main Experiment Station Horticulture, Narendra Deva University of Agriculture and Tech., Kumarganj, Faizabad (U.P.) during the year 2007-08 and 2008-09, to evaluate the response of organic manures, inorganic fertilizers, biofertilizers and their combination with foliar spray of 0.4 per cent boron on yield, physico-chemical characters and economic feasibility of bael cv. NARENDRA BAEL-9. The physical characters of fruit viz., maximum fruit length, width, weight, volume, reduction of skull thickness, fibre content, number of seed per fruit, mucilage content, time of fruit maturity, maximum advancement of fruit maturity and fruit yield were recorded with the application of $\mathrm{T}_{10}(100 \% \mathrm{NPKB}+$ biofertilizers + biopressmud + FYM) closely followed by $\mathrm{T}_{14}(50 \% \mathrm{NPKB}+$ biofertilizers + biopressmud + FYM $)$. However, the chemical composition of fruit viz., maximum TSS, ascorbic acid, reducing sugars, non reducing sugar, total sugars and minimum acid content were recorded with the application of $\mathrm{T}_{10}(100 \% \mathrm{NPKB}+$ biofertilizers + biopressmud + FYM $)$ which was at par with $\mathrm{T}_{14}(50 \% \mathrm{NPKB}+$ biofertilizers + biopressmud + FYM) during both the years of experimentation. The maximum net return Rs. 72,622.23 and Rs. 83,897.63 per hectare were obtained with $\mathrm{T}_{10}(100 \% \mathrm{NPKB}+$ biofertilizers + biopressmud + FYM) followed by Rs. 72121.70 and Rs. 83810.50 under $T_{14}(50 \%$ NPKB + biofertilizers + biopressmud + FYM) treatment, and net return rupee ${ }^{-1}$ invested $\left(\mathrm{C}: \mathrm{B}\right.$ ratio) was maximum in $\mathrm{T}_{14}(50 \% \mathrm{NPKB}+$ biofertilizers + biopressmud + FYM) 1:3.90 and 1:3.96 followed by 1:3.04 and 1:3.17 under $\mathrm{T}_{10}$ $(100 \%$ NPKB + biofertilizers + biopressmud + FYM $)$ treatments. It was minimum in control, 1:2.82 and 1:2.83 during both the year 2007-08 and 2008-09, respectively. The higher cost: benefit ratio was obtained in $\mathrm{T}_{14}(50 \%$ NPKB + biofertilizers + biopressmud + FYM) due to low cost of production. All the treatments were effective to improve the yield, physico-chemical characters and reduce the cost: benefit ratio as compared with control, due to effect of integrated nutrient management and foliar spray of boron.

KEY WORDS : Biofertilizers, Biopressmud, FYM, NPK, Yield, Quality, Economic, Bael

HOW TO CITE THIS ARTICLE : Singh, J.K., Singh, D.K. and Singh, H.K. (2014). Integrated nutrient management studies on yield, physico-chemical characteristics and economic feasibility of bael (Aegle marmelos Correa) cv. NARENDRA BAEL-9. Asian J. Hort., 9(2) : 342-346. 